\title{
OBITUARIES
}

\section{Dr. D. O. Morgan}

Dr. Daniel Owen Morgan, of St. Catharine's College, Cambridge, and University lecturer in animal pathology, formerly senior lecturer in zoology, University of Edinburgh, died in Cambridge on November 17, aged sixty-six. $\mathrm{He}$ was born on August 19, 1893, was educated at Tregaron County School, and after serving as a signaller during the First World War entered the University College of Wales, Aberystwyth, in 1919, reading zoology and agriculture and specializing in helminthology. His postgraduate researches were conducted under the supervision of Prof. R. T. Leiper, at the London School of Hygiene and Tropical Medicine, and included studies on the systematics of the trematode family Opisthorchidae, the bionomics of the potato eelworm Heterodera schachtii, and a survey of the helminths of domestic and wild animals in Hertfordshire.

During the years 1923-33 he held the post of field officer and senior research assistant at the Institute of Agricultural Parasitology of the London School of Hygiene and Tropical Medicine, and during this time published twenty-three papers on parasitological subjects. In 1933, he was appointed to a senior lectureship in zoology in the University of Edinburgh and became responsible for the teaching of helminth. ology to veterinary undergraduates reading for the Royal College of Veterinary Surgeons diploma and the University degree in veterinary science. In addition, he was responsible for the postgraduate courses in helminthology for the diplomas of tropical veterinary medicine, tropical medicine and public health, while during the War an emergency short course in helminthology for medical officers was his concern.

Despite an extensive teaching programme he found time for research, and his outstanding contribution was the study of the helminth population of Scottish hill sheep and the discovery of the 'spring rise' phenomenon of worm egg output in these sheep. His work on hill sheep has stimulated numerous researches on this and allied problems both in Great Britain and throughout the world.

In 1952 he moved to Cambridge and was responsible for the course in parasitology to veterinary students. He greatly loved Cambridge, its life, and was particularly fond of his College, St. Catharine's. He was a man of abounding kindness and encouragement, and will be remembered by the hundreds of students whom he guided and sadly missed by his colleagues.

E. J. L. SouLsBy

\section{Mr. William Dallimore, I.S.O., V.M.H.}

THE death of William Dallimore took place suddenly at his home near Tonbridge, Kent, on November 7, in his eighty-ninth year. $\mathrm{He}$ entered the Royal Botanic Gardens, Kew, as a young student in 1891 and his official connexion with this institution extended over forty-five years. His earlier years at Kew were spent mainly in the Arboretum, of which he later had charge. It was this close association with a rich collection of living plants in his early years that enabled Dallimore, with his keen powers of observation and a good memory, to build up for himself his great knowledge of trees and shrubs which he was to put to such good effect in later years. $\mathrm{He}$ was one of Britain's leading authorities on trees and shrubs for half a century, having maintained his keen mental powers to the full until the ond of his long life. He devoted special attention to the conifers, and his "Handbook of Coniferæ" (written in collaboration with the late A. Bruce Jackson), which first appeared in 1923, has remained a standard work.

Another of Dallimore's notable achievements was the tremendous part he played in starting and developing the National Pinetum at Bedgebury in Kent, a joint undertaking on the part of Kew and the Forestry Commission, commenced in 1925. The fine specimens of pines and other conifers now to be seen at Bedgebury constitute a fitting, living memorial to him. He supervised the raising of these trees from seed in many instances. One of the main thoroughfares in the Pinetum has, in fact, been named Dallimore Avenue. On his retirement from Kew in 1936, Dallimore moved to Kent to live, and continued to act in an advisory capacity in connexion with Bedgebury almost to the time of his death.

At Kew, Dallimore ceased to have charge of the Arboretum in 1909 when he was transferred to the Museum staff, his first task being to initiate and build up a museum of British forestry (now the Wood Museum). His knowledge of arboriculture and forestry was of great assistance to him in this. $\mathrm{He}$ became keeper of the Museums of Economic Botany in 1926. His published works included two other books, one on pruning and one on holly, yew and box; also numerous articles in horticultural, botanical and forestry journals.

The Kew Guild, an association of past and present Kew men, came into being in the early 1890 's, largely as a result of Dallimore's initiative and energy. He himself became president of the Kew Guild in 1926. Dallimore had other interests besides plants. For many years he was an enthusiastic bowls player. He was also churchwarden at the Kew parish church. With his keen sense of humour and his amusing narratives he was always a popular figure. His two daughters survive him. F. N. Howes

\section{Mr. A. W. Siddons}

IN no subject of the curriculum has the method of teaching undergone greater change in the past fifty years than in mathematics. Before the turn of the century, the school course contained little more than arithmetic, manipulative algebra and the rote learning (sometimes even in Latin) of Euclid's proofs. The revolt was led by Rawdon Levett, mathematics master at King Edward's School, Birmingham, who, through a letter in Nature of May 26, 1870, pleaded for the formation of an Anti-Euclid Association. It was left to one of his greatest pupils, Arthur Warry Siddons, to see the change effected, Euclid's strangle. hold broken and geometry established as a suitable tool for school use.

Mr. Siddons devoted his whole life to school mathematics, though he might well have attained 
eminence in the university field. He was a scholar of Jesus College, Cambridge, and was fifth Wrangler in 1898, immediately below Jeans and Hardy. In the following year he read natural science, and again took a first. His only appointment was at Harrow School ; here he taught mathematics with increasing brilliance and success until his retirement in 1936, and in these years he earned the affection of generations of Harrovians. In 1902 Jesus College elected him to a fellowship and, in December of the same year at the age of twenty-six, he was appointed to a University Syndicate to discuss mathematical requirements. The report stated that any geometrical proof would be accepted provided it appeared "to form part of a systematic treatment of the subject" ; Levett's cherished freedom was achieved. From this time to the end of his busy life, Siddons was engaged in converting the rigid logic of mathematics into a form suitable for young minds. In this his greatest collaborator was Charles Godfrey; as a team they had the ability to put into practice their progressive ideas and, when necessary, to write the appropriate text-books.

In addition to an intensely happy family life and to his devoted service to Harrow, Siddons's great joy was his work with the Mathematical Association. In 1902 he was elected secretary of the newly formed Teaching Committee. The reports prepared by this Committee now cover the whole field of school mathematics, and in preparing many of them, Siddons (and his life-long friend, C. O. Tuckey) took a leading part. The Association recorded its gratitude by electing him as president in 1935-he was the first schoolmaster ever to achieve this distinctionand in 1958 it bestowed the rare privilege of honorary membership.

With all his ability, all this distinction, Siddons was a very simple person. He was a great conversationalist and a most lovable man: in the Harrow tradition he was very fond of singing, and the School on the Hill has cause to remember his genius as a gardener and maker of lawns. He claimed that in his school-days he found mathematics difficult; perhaps this explains his success as a teacher and his passion for simplicity within the limits of exactness. To the end his mind was crystal clear, and he died peacefully in his sleep on November 10. Those who knew him well will miss his warm friendship, and the whole body of teachers and taught in mathematics is grateful for his life and his labours.

W. J. LANGFORD

\section{NEWS and VIEWS}

International Scientific Relationships:

\section{Dr. Detlev W. Bronk, For.Mem.R.S.}

A spectal medal (Fig. 1) has been awarded to Dr. Detlev W. Bronk, president of the Rockefeller Institute, by the Society for Promoting International Scientific Relationships. The award has been made for Dr. Bronk's accomplishments in fostering the promotion of scientific research and international

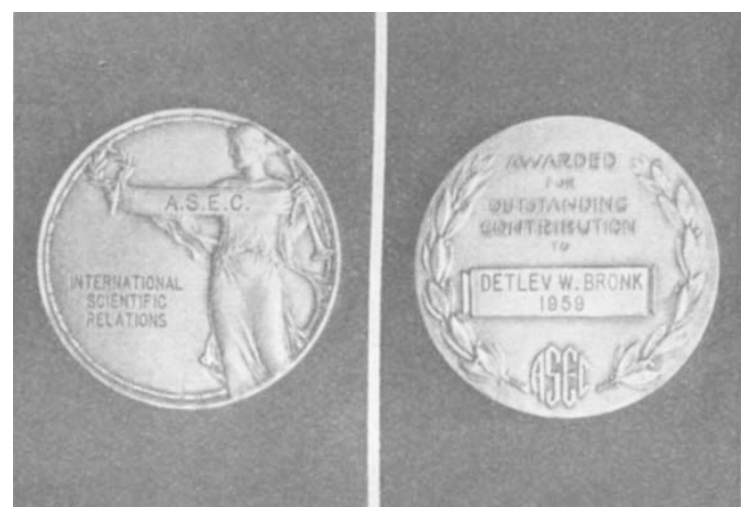

Fig. 1

co-operation through exchanges of scholars. The medal was presented on November 24 by Dr. Herman F. Mark, honorary president of the Society and director of the Institute of Polymer Research at the Polytechnic Institute of Brooklyn. At the meeting Dr. Alan T. Waterman, director of the National Science Foundation, delivered an address on "Science and the Progress of Man".

Bristol City Museums :

Dr. F. S. Wallis

Dr. F. S. WaLlis will bring to a close his long and distinguished service to the Bristol City Museums in
May of next year. A Bristol man, he was educated at the Fairfield Secondary School, Bristol, and at the University of Bristol, where his academic career was broken by service in the First World War with the Royal Warwickshire Regiment and the R.F.C., later the R.A.F. He graduated with first-class honours in geology in 1920, and afterwards took his M.Sc., his Ph.D., and finally, in 1930, his D.Sc. He was appointed assistant curator in geology after his first graduation and has devoted his life to the welfare and development of the Bristol Museum and Art Gallery, of which he was promoted to be deputy director in 1930. On the division of the Museum and Art Gallery in 1945, he became director of the City Museum-now 'Museums' as they include the Blaise Castle Folk Museum. He has never forgotten his first love as he has held for more than thirty years the post of special lecturer in sedimentary petrology in the University of Bristol and has since 1936 taken the evening tutorial class in geology there. He has always been interested in adult education and has lectured extensively to members of various organiza. tions in Bristol and the surrounding district. For his field-work he was awarded the Lvell Fund of the Geological Society. In the museums field, he has long laboured for better lay-outs, more didactic exhibits and more artistic displays, and he has not spared himself in extending good ideas and projects of reorganization throughout the museums of the south-west of Britain. He served with unassuming distinction as president of the South Western Museums and Art Galleries Association and also, in 1956, of the national body, the Museums Association, in which he now ranks as an elder statesman. He gave notable service to the Joint Committee of the Museums Association and the Carnegie United Kingdom Trustees, both as a member and for five years as its chairman, in the worthy task of allocating grants for the reorganization of smaller provincial museums. He was war-time editor of the Museums 